\title{
The perception of viewers on female role portrayals in Malaysian television advertisements
}

\begin{abstract}
The purpose of the study is to examine the extent to which there are gender differences in advertisements in Malaysia. Primary data for the study was based on questionnaires that were completed by 200 university undergraduates from Universiti Putra Malaysia (UPM) and Universiti Kebangsaan Malaysia (UKM). The study found that there were significant differences, in general perceptions of female role portrayals in advertisements, among the male and female viewers. The study also found that the differences in gender and race could have caused different perceptions, on female role portrayals in television advertisements. The study further found that certain portrayals of women in television advertisements were considered offensive, particularly by female viewers and they further felt that there is a need for a change in such portrayals.
\end{abstract}

Keyword: Female role portrayals; Television advertisements; Perception of viewers 